\title{
PENICILLIN ANTIBODY
}

\author{
BY \\ G. W. G. BIRD \\ From the Armed Forces Medical College, Poona, India
}

(RECEIVED FOR PUBLICATION AUGUST 4, 1959)

\begin{abstract}
A serum which specifically agglutinated penicillin-coated erythrocytes is described. The active constituent had the charac eristics of an antibody. Its laboratory and clinical significance is discussed.
\end{abstract}

The antibiotics chloramphenicol (Glazko, Wolf, and Dill, 1949), penicillin, streptomycin, aureomycin, and terramycin (Seigneurin, Act.ard, and Magnin, 1955) are readily adsorbed to erythrocytes. Seigneurin, Magnin, and Fils (1958) observed that adsorbed penicillin, streptomycin, aureomycin, and erythromycin resist elution, yet staphylococci were killed by washed erythrocytes which had been exposed to these antibiotics. Seigneurin et al. presumed that this was due to slow release of the antibiotics and considered that erythrocytes thus play an important part in the successful outcome of antibiotic therapy.

The discovery of a circulating antibody to penicillin (Ley, Harris, Brinkley, Liles, Jack, and Cahan, 1958b), which specifically agglutinated erythrocytes coated with penicillin, has introduced a relatively simple means of studying the immunological aspects of antibiotic therapy. The antibody agglutinated erythrocytes treated with penicillins $\mathbf{G}, \mathbf{O}$, and $\mathbf{K}$, or with a penicillin derivative, synnematin $B$, but not those treated with several other antibiotics. Prior exposure of the serum to penicillin inhibited the antibody. Penicillin which had been inactivated with penicillinase failed to sensitize erythrocytes to the antibody ; penicillin-coated erythrocytes, however, were agglutinated by the antibody even after they had been exposed to penicillinase for four hours. The antibody was present in the sera of 25 out of almost 2.000 normal blood donors $(1.25 \%$ ) (Ley, cited by Greenwalt, 1958), in 41 out of 413 hospital patients $(9.9 \%)$, and in seven out of 21 persons $(33.3 \%)$ known to be hypersensitive to penicillin (Ley, Cahan, and Mayer, 1958a). In some sera the antibody was demonstrated by direct agglutination and in others by the antiglobulin test. All persons whose sera contained the antibody had received or were receiving penicillin; only a minority of these had demonstrated clinical sensitivity to penicillin

\section{Characteristics of a Penicillin Antibody}

This paper briefly describes some characteristics of an antibody to penicillin found during a survey of the sera of hospital patients in Poona. The methods adopted were those of Ley et al. (1958b). The antibody was the only strong one out of five examples found in the sera of 187 patients $(2.7 \%)$. It agglutinated red cells coated with penicillin but not untreated cells or those coated with streptomycin.

The antibody was active in both slide and tube tests. Agglutination was delicate; vigorously rocking the slides or shaking the tubes caused the red cells to disaggregate. Red cells suspended in isotonic saline, tested in tubes against doubling dilutions of serum, were agglutinated to a titre of 16. When $A B$ serum was substituted for saline there was no significant increase in titre; cells suspended in albumin were not agglutinated.

The agglutinin acted as strongly at room temperature as at 37 or $4^{\circ} \mathrm{C}$. It was specifically inhibited by previous exposure of the serum to penicillin for 30 minutes. A concentration of at least 125,000 units of sodium penicillin $G$ per millilitre of isotonic saline was necessary; this is over 20 times the concentration which was required by Ley et al. (1958b) to inhibit one of their antibodies. When agglutinates were carefully pipetted on to a slide, the addition of a drop of penicillin solution caused them to break up; they were unaffected by streptomycin or saline solution.

The serum, when undiluted or diluted 1 in 2 , produced large loose agglutinates which looked 
more like those formed by strong anti-Le ${ }^{a}$ sera than like heavy rouleaux; perhaps this type of agglutination occurs when the reactive antigen is passively attached to the red cells. Rouleaux formation was excluded because untreated cells or those treated with streptomycin remained evenly dispersed when tested under the same conditions.

The agglutinin was adsorbed by penicillincoated erythrocytes and eluted; the eluates specifically agglutinated "penicillinized" cells. The serum became inactive after incubation with the proteolytic enzyme trypsin for two hours at $37^{\circ}$ C.; the active component is therefore a protein.

The patient from whom the serum was obtained had received 1 million units of penicillin twice a day for 10 days three months previously. He was clearly not hypersensitive to penicillin, because he had been given a penicillin injection just before the antibody was reported to the clinicians. A second sample of serum collected two weeks later showed no change in antibody titre.

\section{Discussion}

The serum protein described has many of the characteristics of an antibody. Although the history is suggestive, there is really no evidence that it is of immune origin; on the other hand its capacity to act as well at low temperatures as at $37^{\circ} \mathrm{C}$., its non-potentiation by $\mathrm{AB}$ serum, its inactivity in albumin, and its failure to increase in titre two weeks after the appropriate stimulus indicate that it might not be an immune antibody. It is thus uncertain that it is an antibody in the strict sense ; however, the term is justified in that it is now applied (Wilson and Miles, 1955) to a certain type of serum protein which reacts specifically with antigen without insistence that its synthesis is dependent on introduction of the antigen.

Agglutinins for penicillin-coated erythrocytes are of laboratory, and possibly clinical, significance. The widespread practice of storing panels of fully grouped erythrocytes in ACD-penicillinstreptomycin mixtures may seriously hinder the identification of blood group antibodies. Penicillin should no longer be a component of erythrocyte preservative solutions.

A more dangerous practice, fortunately uncommon, is the addition of penicillin to blood stored for transfusion. The author knows of two blood banks in which this is a routine measure.
These institutions have experienced some haemolytic transfusion reactions which they could not ascribe to any known blood group antibody ; in the light of recent developments it is possible that anti-penicillin antibodies were responsible. It may be stated that it is unwise to add penicillin to banked blood for a different reason. The most dangerous bacterial contaminants of stored blood are certain strains of $E$. coli and Ps. aeruginosa which multiply readily at blood bank temperature (James and Joan Stokes, 1957) ; these organisms are insensitive to penicillin.

The clinical significance of anti-penicillin antibody is obscure. It appears from the author's case and the experience of Ley and his colleagues that the presence of antibody is not necessarily associated with clinical sensitivity to penicillin; nevertheless Ley et al. (1958a) found a higher incidence of antibody among persons sensitive to penicillin than among others. It is possible that the antibody responsible for clinical sensitivity is different to the agglutinin for penicillin-coated erythrocytes.

Ley et al. (1958a) observed, in a person whose serum contained the agglutinin, that the survival time of transfused erythrocytes previously exposed to high concentrations of penicillin $(10-50 \mathrm{mg} . / \mathrm{ml}$.) was greatly decreased, whereas it was almost normal in a control. After they gave heavy doses of penicillin (18 million units a day) to a patient with these antibodies in her serum, the erythrocytes developed a positive antiglobulin test and there was a significant fall in the haematocrit. Such doses are unusual ; the occurrence of antibody-induced haemolytic anaemia consequent upon penicillin therapy would thus be a remote possibility.

The antibacterial effect of penicillin in vitro was not impaired in the presence of anti-penicillin serum (Ley et al., 1958a); moreover, serum penicillin levels, after the antibiotic was administered to persons who had made the antibody, were the same as in controls. Thus, although the haemagglutinating capacity of the antibody was inhibited by penicillin, the antibody did not impair the effect of penicillin on bacteria. This might have been due to excess penicillin ; in view of the high concentrations of penicillin required to inhibit, a more reasonable explanation is that the complex of penicillin and antibody has as great an antibacterial effect as penicillin alone.

Hazards arising from acquired bacterial insensitivity to penicillin, those of clinical hypersensitivity to penicillin, and those possibly associated with agglutinins for penicillin-coated 
erythrocytes make it imperative that the indiscriminate administration of penicillin should be avoided.

I am indebted to Lieutenant-Colonel S. N. Chak for a generous supply of serum.

\section{REFERENCES}

Glazko, A. J., Wolf, L. M., and Dill, W. A. (1949). Proc. Soc. exp. Biol.' (N.Y.), 72, 602 .
James, J. D., and Joan Stokes, E, (1957) Brit, med, J., 2,1389 Ley, A. B. Cited by Greenwalt, T. J. (1958). Vox Sang (Basel), (n.s.) 3, 77.

Cahan, A., and Mayer, K. (1958a). Programme of the Seventh Congress of the International Society of Blood Transfusion, Rome, Abstract No. 149, p. 127.

Harris, J. P., Brinkley, M. Liles, B., Jack, J. A., and Cahan, A. (1958b). Science, 127, 1118 .

Seigneurin, R. Achard, M.-L., and Magnin, R. (1955), Ann. Inst.

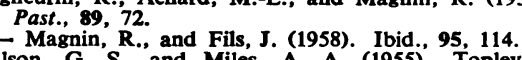

Wilson, G. S., and Miles, A. A. (1955). Topley and Wilson's Principles of Bacteriology and Immunity, 4th ed., Vol. I, p. 224 Arnold, London. 